\title{
ПСИХОЛОГІЧНІ ОСОБЛИВОСТІ ВПЛИВУ СТРЕСУ НА ВИНИКНЕННЯ ПСИХОСОМАТИЧНИХ РОЗЛАДІВ У ДІТЕЙ СТАРШОГО ШКІЛЬНОГО ВІКУ
}

\section{Грицюк Ірина}

Волинський національний університет імені Лесі Українки, м. Луцьк, Україна

hrytsiuk_ira@ukr.net

ORCID: https://orcid.org/0000-0001-6988-6012

\section{Хлівна Олександра}

Волинський національний університет імені Лесі Українки, м. Луцьк, Україна

hlivnaoleksandra@gmail.com

ORCID: https://orcid.org/0000-0002-7782-4038

Мета: розкрити погляди на сучасне бачення психосоматичних розладів, що виникають у дітей старшого шкільного віку в умовах сучасного інформаційно насиченого та агресивного середовища. Висвітлити результати емпіричного дослідження 3 цієї тематики. Проаналізувати різноманіття досліджень, що стосуються впливу стресу на дітей старшого шкільного віку та виникнення у зв'язку зі стресовими ситуаціями психосоматичних розладів. Визначити психологічні і психосоматичні аспекти впливу стресу на життя та здоров’я дітей старшого шкільного віку. Опираючись на погляди відомих науковців, зокрема 3. Фройда, про те, що всі органічні страждання мають психологічну зумовленість, розкрити своє бачення впливу емоційної стійкості та самооцінки на функціонування внутрішніх органів.

Методи: теоретичні (аналіз проблеми на підставі вивчення наукової літератури, систематизація та узагальнення одержаної інформації). Та емпіричні: психодіагностичні методики (Гісенський опитувальник соматичних скарг, контрольний перелік ознак психопатії, тест-опитувальник Г. Айзенка для діагностики властивостей і типу темпераменту, шкала психологічного стресу RSM-25, малюнковий тест «Автопортрет»), що дозволили нам розкрити наше бачення впливу стресу на появу психосоматичних порушень.

Результати: у ході теоретичного аналізу виявили, що погляди на сучасну психосоматику виходять за рамки уявлень лише про здоров'я чи хворобу. Так само і поняття «стрес» виходить за рамки розуміння «погано» чи «добре».

ISSN 2308-3743 (Online), ISSN 2227-1376 (Print)

(C) Грицюк I., Хлівна О., 2021. Ця стаття відкритого доступу на умовах CC BY-NC 4.0 
Зазначено про необхідність враховувати, що більшість людей, в тому числі й діти, в сучасному суспільстві знаходиться під впливом стресу, бо в часи науково-технічної революції, в які ми живемо, посилюється психічна діяльність людей. У результаті дослідження також проаналізовано особливість дітей старшого шкільного віку засвоювати й переробляти великий обсяг інформації, необхідність швидкої адаптації, перші пошуки професійної реалізації, пошук себе тощо. Розглянуто виникнення проблеми емоційного стресу, тобто напруження й перенапруження фізіологічних систем організму під впливом емоційних чинників, як причини психосоматичних розладів. Аналіз отриманих даних полягав у виявленні відмінностей між представниками двох груп - групи емоційно стійких респондентів (середня емоційна стійкість та висока емоційна стійкість) з низьким рівнем стресу та групи емоційно нестійких респондентів (висока емоційна нестійкість та дуже висока емоційна нестійкість) з середнім рівнем стресу. Значна увага приділена опису психологічної картини хвороби, оскільки від такого знання залежать наступні терапевтичні заходи.

Висновки. В умовах стресу, а також з урахуванням нестійкої або заниженої самооцінки діти старшого шкільного віку більш схильні до психосоматичних розладів серцево-судинної системи, системи органів травлення. Узагальнили результати впливу психологічних i соціальних факторів, яким $\epsilon$, власне, стрес. Прийшли до розуміння афективно-емоційних факторів впливу на виникнення психосоматичних порушень.

Ключові слова: психологічний стрес, психосоматика, психічна напруга, дезорганізація поведінки, здоров'я, хвороба, психосоматичне порушення.

Hrytsiuk Irina, Hlivna Oleksandra Psychological features of the influence of stress on the occurrence of psychosomatic disorders in children of senior school age.

Purpose: to reveal the modern approaches to psychosomatic disorders that occur in children of senior school age in terms of modern information-rich and aggressive environment. To highlight the empirical research results on this topic. To analyze the diversity of research on the stress effects on older school children and the occurrence of psychosomatic disorders in connection with stressful situations. To identify the psychological and psychosomatic aspects of the stress impact on the lives and health of senior school children. Based on the views of famous scientists, namely S. Freud, that all organic suffering has a psychological condition, to reveal their vision of the emotional stability and self-esteem impact on the internal organs functioning.

Methods: theoretical (problem analysis based on the study of scientific literature, systematization, and generalization of the information obtained). And empirical: psychodiagnostic techniques (Giessen Subjective Complaints List, psychopathy checklist of signs, G. Eisenko test questionnaire to diagnose the properties and type of temperament, RSM-25 psychological stress scale, self-portrait drawing test), which allowed us to reveal the impact of stress on the emergence of psychosomatic disorders. 
Results: with the help of theoretical analysis it was found that views on modern psychosomatics go beyond the notions of only health or disease. Similarly, the concept of "stress" surpasses the understanding of "bad" or "good". It is noted that it is necessary to take into account that the vast majority of people, including children, in modern society are under the influence of stress, because during the scientific and technological revolution, the mental activity of people increases. The study also analyzed the peculiarity of high school children to learn and process a large amount of information, the need for rapid adaptation, the first search for professional realization, self-seeking, and so on.

The issue of psychological stress, i.e. stress and overstrain of physiological systems of the body under the influence of emotional factors as causes of psychosomatic disorders. The analysis of the obtained data consisted in identifying differences between representatives of two groups - a group of emotionally stable respondents (average emotional stability and high emotional stability) with low stress and a group of emotionally unstable respondents (high emotional instability and very high emotional instability) with medium stress. Considerable attention is paid to the description of the psychological picture of the disease, as the following therapeutic measures depend on such knowledge.

Conclusions. In terms of stress, as well as taking into account unstable or low self-esteem, senior school children are more prone to psychosomatic disorders of the cardiovascular system, digestive system. We summarized the results of the psychological and social factors' influence. We decided that affective and emotional factors influence the occurrence of psychosomatic disorders.

Keywords: psychological stress, psychosomatics, mental stress, behavior disorganization, health, disease, psychosomatic disorder.

Грыцюк Ирина, Хливна Александра. Психологические особенности влияния стресса на возникновение психосоматических расстройств у детей старшего школьного возраста.

Цель: раскрыть взгляды на современное видение психосоматических расстройств, возникающих у детей старшего школьного возраста в условиях современной информационно насыщенной и агрессивной среды. Осветить результаты эмпирического исследования по данной тематике. Проанализировать многообразие исследований, касающихся влияния стресса на детей старшего школьного возраста и возникновения в связи со стрессовыми ситуациями психосоматических расстройств. Определить психологические и психосоматические аспекты влияния стресса на жизнь и здоровье детей старшего школьного возраста. Опираясь на взгляды известных ученых, в частности Фрейда о том, что все органические страдания имеют психологическую обусловленность, раскрыть свое видение влияния эмоциональной устойчивости и самооценки на функционирование внутренних органов.

Методы: теоретические (анализ проблемы на основе изучения научной литературы, систематизация и обобщение полученной информации). И 
эмпирические: психодиагностические методики (Гиссенский опросник соматических жалоб, контрольный перечень признаков психопатии, тестопросник Г. Айзенко для диагностики свойств и типа темперамента, шкала психологического стресса RSM-25, рисуночный тест «Автопортрет»), которые позволили нам раскрыть наше видение влияния стресса на появление психосоматических нарушений.

Результаты: в ходе теоретического анализа было выявлено, что взгляды на современную психосоматику выходят за рамки представлений только о здоровье или болезни. Так же и понятие «стресс» выходит за рамки понятия «плохо» или «хорошо». И необходимо учитывать, что подавляющее большинство людей, в том числе и дети, в современном обществе находится под влиянием стресса, потому что во времена научно-технической революции, в которые мы живем, усиливается психическая деятельность людей. У детей старшего школьного возраста это связано с необходимостью усвоения и переработки большого объема информации, необходимости в быстрой адаптации, первых поисков профессиональной реализации, поиска себя и тому подобное. Поэтому и возникает проблема эмоционального стресса, то есть напряжения и перенапряжения физиологических систем организма под воздействием эмоциональных факторов, которая и вызывает психосоматические расстройства.

Выводы. В условиях стресса, а также с учетом неустойчивой или заниженной самооценки дети старшего школьного возраста более склонны к психосоматическим расстройствам сердечно-сосудистой системы и органов пищеварения. Обобщили результаты влияния психологических и социальных факторов, каким, собственно, и есть стресс. Пришли к пониманию влияния аффективно-эмоциональных факторов на возникновение психосоматических нарушений.

Ключевые слова: психологический стресс, психосоматика, психическое напряжение, дезорганизация поведения, здоровье, болезнь, психосоматические нарушения.

Вступ. Актуальність зазначеної теми очевидна, оскільки ми перебуваємо в умовах перехідного періоду формування Української державності, коли інформаційне суспільство несе переважно негативну інформацію та агресивні посили. Становлення дітей старшого шкільного віку, коли накладаються і вікова криза 17 років, i психологічна неготовність батьків правильно впливати на їх виховання та становлення тощо, формують у них неуспішність, пасивність, а також проблеми зі здоров'ям, що мають часто психосоматичний характер.

Мета дослідження: теоретично та емпірично вивчити вплив стресу на виникнення психосоматичних розладів, зокрема в дітей 
старшого шкільного віку. Завдання: здійснити теоретичний аналіз проблематики впливу стресу на психосоматичні порушення; розкрити проблематику стресу в дітей старшого шкільного віку; проаналізувати результати проведеного нами емпіричного дослідження.

Психологічний стрес - це стан надмірної психічної напруженості i дезорганізації поведінки. А психосоматика - це, відповідно, відображення через тіло психічного життя, яке охоплює як тілесні прояви емоцій, так і відображення інших підсвідомих процесів. Тому психологічні проблеми дитини, зокрема старшого шкільного віку, знаходять відображення в психосоматичних проявах.

Зміна поведінки під час стресу - специфічний i більше інтегральний показник характеру відповіді на вплив, ніж окремі функціональні показники. У стані стресу в дитини часто домінує форма поведінки з підвищенням збудливості, що виражається в дезорганізації поведінки, втрати ряду раніше набутих реакцій, переважання стереотипних відповідей, появі помилкових дій.

Ще у XIX ст. 3. Фрейд стверджував, що при неврозах сильне емоційне збудження призводить до психосоматичних захворювань (Фрейд, 2015). У ХX ст. Ф. Александер, прихильник тілесноорієнтованої психотерапії, переконливо доводив, що затяжні, стереотипно повторювані негативні емоції не обмежуються лише психологічними проявами, а призводять до розвитку специфічних тілесних розладів. Останні проявляються в тих системах організму, 3 якими дані емоції мають «спорідненість». Так, почуття гніву призводить до формування серцево-судинних захворювань, а почуття залежності - захворювань шлунково-кишкового тракту тощо (Александер, 2001).

Будь-які негативні стани, зокрема й стрес, викликають психічний дискомфорт, який пов'язаний або 3 актуальною психологічною проблемою, або з певною життєвою ситуацією. Організм починає мобілізуватись і спрямовує усі свої ресурси на подолання цього дискомфорту. Але в результаті дії сильного чи часто повторюваного подразника відбувається виснаження компенсаторних можливостей організму. Наслідком цього є перехід реакції тривоги, або наступної стадії резистентності, у фазу виснаження. У загальнобіологічному плані, на думку Ф. Меєрсона, стрес-реакція сформувалася в процесі еволюції як необхідна неспецифічна ланка більш складного цілісного 
механізму адаптації (Меєрсон, 1982). 3 іншого боку, як відомо, стрес $\epsilon$ важливою частиною не лише механізму адаптації, але й патогенезу багатьох захворювань (Davidson, 2012).

Велике значення вивченню емоцій у дітей у зв'язку 3 виникненням соматичної патології надавали дослідники психоаналітичної школи, які заперечували біологічну корисність емоцій i розглядали негативні емоції як основу соматичного неблагополуччя. Певна специфічність емоційних (поведінкових) реакцій у дітей відзначалася багатьма дослідниками.

Психічні розлади, особливо депресії та неврози, зазвичай супроводжуються порушеннями соматичних функцій, насамперед вегетативних. Між тілесними й душевними хворобами розташована перехідна область психосоматичних порушень, які $\epsilon$ функціональними і протікають без органічних змін органів і тканин. Подібні порушення виникають під явним або прихованим впливом психічного фактора, від ступеня впливу якого залежить виразність симптоматики. Ця симптоматика добре реагує на психотерапію i погано - на ліки (Харченко, 2015).

Психосоматичні порушення у широкому сенсі слова включають конверсійні та соматоформні розлади, розлади прийому їжі i виділення, сну і статевої функції. До конверсійних розладів належать псевдоневрологічні порушення функцій органів чуттів i рухів, ксоматоформних - іпохондричні розлади, соматоформна та вегетативна дисфункція і хронічні соматоформні больові розлади (Shalev, Entringer, Wadhwa, 2013).

Виділяють психосоматичні хвороби у вузькому сенсі слова (органічні психосоматози), вони становлять «святу сімку». Першим найповнішу класифікацію психосоматичних розладів запропонував М. Блейлер 1970 року, виокремивши три їх види.

1. Так звані класичні психосоматози, тобто психосоматичні захворювання, що супроводжуються органічною патологією внутрішніх органів і систем.

2. Функціональні психосоматичні розлади, які спостерігають найчастіше. Вони мають стійкий перебіг. У деяких випадках їх зараховують до так званих системних неврозів.

3. Психосоматичні розлади в ширшому (непрямому) розумінні. Здоров’я порушується через особливості поведінки людини, що 
пояснюється характером особистості та іiі переживаннями (Dube, Fairweather, Pearson,2009).

Етіологія психосоматичних захворювань у дітей тісно пов'яна із станом ЦНС дитини. А в етіології неврозів у дітей основне місце займають аномалії виховання i несприятливі сімейні умови, викликані неправильною поведінкою батьків. На цьому тлі зростаючих невротичних розладів зростає кількість хворих дітей, у яких під впливом згаданих та інших психогенних факторів виникають соматичні захворювання серцево-судинної, дихальної систем, шлунково-кишкового тракту, шкіри (Наказава, 2018).

Етіологія і патогенез психосоматичних розладів досі з'ясовані не достатньо. Певно, генез їхній має багатофакторний характер. Різноманітні ланки пояснює теорія специфічності, що вказує на особливі (неусвідомлені) конфлікти, які зумовлюють специфічні розлади (Александер, 2001). За неспецифічною теорією, будь-який стрес може спричинити патологічні зміни в генетично ослабленому організмі.

Найбільш важливу роль у механізмі розвитку емоційного стресу відіграють первинні розлади у вентромедіальному відділі гіпоталамуса, базальнолатеральної області мигдалини, перегородці і ретикулярної формації. Саме неузгодженість діяльності в цих структурах призводить до зміни нормального функціонування серцево-судинної системи, шлунково-кишкового тракту, згортальної системи крові, розладу імунної системи (Felitti, Anda, 2010) .

Методи та процедура дослідження. Емпіричне вивчення впливу стресу на виникнення психосоматичних розладів у дітей старшого шкільного віку відбувалось на основі закладів професійної освіти м. Луцька (упродовж 2019-2020 років). Проводили наше дослідження на базі училищ (Луцький педагогічний коледж та ДПТНЗ «Луцьке вище професійне училище № 9»), де навчаються діти, які обрали професійну освіту. В дослідженні взяли участь 36 респондентів. У своєму дослідженні ми не враховували статеві особливості, оскільки більшість досліджуваних становили особи жіночої статі (30 респонденток) та лише 6 осіб чоловічої статі. Середній вік досліджуваних - 18 років. Ми запропонували їм такі методики: Гісенський опитувальник соматичних скарг, контрольний перелік ознак психопатії, тест-опитувальник Г. Айзенка для діагностики властивостей і типу темпераменту (ЕP Q, форма А), 
шкала психологічного стресу RSM-25, малюнковий тест «Автопортрет».

Обговорення результатів. За допомогою вибраних методик ми мали змогу охарактеризувати вплив стресу на виникнення психосоматичних розладів у старшому шкільному віці. Обробка результатів після проведення опитувальника шкали психологічного стресу RSM-25 полягала в тому, щоб підрахувати загальну кількість балів, відповідно до кожного твердження.

Отже, проаналізувавши результати проведеного опитувальника, ми дійшли висновку, що найбільша кількість опитаних (63\%) набрали таку кількість балів, що відповідає середньому рівню стресу. Решта $37 \%$ респондентів набрали таку кількість балів, що відповідає низькому рівню стресу i, відповідно, характеризує стан психологічної адаптованості до робочих навантажень.

Наступним тестом, що був представлений до уваги старших учнів, був тест-опитувальник Г. Айзенка для діагностики властивостей і типу темпераменту (EP Q, форма А), що дав змогу оцінити респондентів за такими шкалами: шкала інтроверсіїекстраверсії, шкала емоційна стійкість-нестійкість, шкала скритністьвідвертість (щирість).

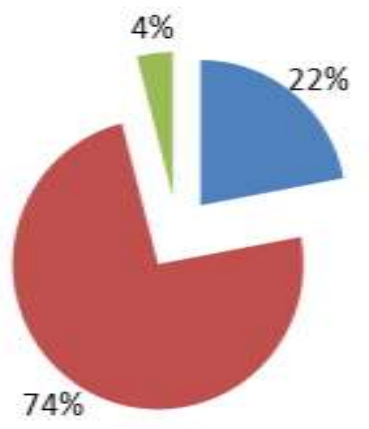

помірна інтроверсія

- Помірна екстраверсія

Екстраверсія

\section{Рис.1. Відсотковий розподіл за тест-опитувальником Г. Айзенка для діагностики властивостей типу темпераменту} (EP Q, форма A)

За шкалою інтроверсії-екстраверсії 74\% респондентів отримали результати, які свідчать про помірну екстраверсію. Шкала емоційна стійкість-нестійкість показала, що, по-перше, найбільше діагностованих осіб, а саме $35 \%$, є високо емоційно нестійкими, і подруге, з середнім рівнем з тенденцією до високого рівня. Показники опитаних респондентів наведенні у вигляді діаграми на рис.1. 
Інтерпретуючи методику «Автопортрет», ми взяли до уваги такі ознаки: самооцінка, інтелектуальна та соціальна адекватність, депресія, агресивність, тривожність. У 28\% старших школярів виявили завищену самооцінку. В 11\% опитаних - знижена, $61 \%$ мають адекватну самооцінку. За ознакою інтелектуальної та соціальної адекватності виявили $97 \%$ респондентів. Лише один досліджуваний (3\%) не зовсім адекватно реагує на події, що відбуваються навколо. $33 \%$ опитаних мають схильність до депресивного стану, а решта $67 \%$ отримали результати, що засвідчують у них відсутність депресії. Такі ж самі показники за ознакою агресивності: у 33\% опитаних виявлено схильність до агресії, а в $67 \%$ - ні. Тривожність спостерігається у 42\%, у решти опитаних тривожність відсутня.

Щоб оцінити реальну картину, чи впливає стрес на виникнення соматичних захворювань, ми умовно поділили респондентів на дві групи:

1. Група емоційно стійких респондентів (середня емоційна стійкість та висока емоційна стійкість) з низьким рівнем стресу;

2. Група емоційно нестійких респондентів (висока емоційна нестійкість та дуже висока емоційна нестійкість) 3 середнім рівнем стресу.

Самопочуття на момент обстеження респондентів ми визначали за допомогою Гіссенського опитувальника соматичних скарг. Проаналізувавши проведену методику, ми зробили такий висновок: у більшості респондентів двох груп переважають симптоми за шкалою, яка стосується шлункових скарг. Також спостерігаються високі показники за шкалою «болі в різних частинах тіла» або «ревматичний фактор». У всіх осіб без винятку, які помічають за собою прояв наявних симптомів за описаними вище шкалами, відзначається швидка виснаженість.

Все ж у зіставленні двох умовно сформованих груп спостерігаються симптоми шкали «сердечні скарги» переважно в другої групи, яка становить більшу частину обстежуваних осіб. Це свідчить про те, що в другої групи осіб локалізуються нездужання переважно у серцево-судинній сфері. Усім особам було рекомендовано звернути увагу на своє здоро'я, щоб при частому прояві тих чи тих симптомів звернутися до відповідного фахівця в цій галузі медицини. 
Емоційно нестійкі респонденти, у яких відзначається середній рівень стресу, часто відчувають такі симптоми: серцебиття, відчуття комка в горлі, напади задишки та серцеві напади. Це свідчить про те, що особи другої групи більш схильні до виникнення таких соматичних недуг як артеріальна гіпертензія, ішемічна хвороба серця, кардіоспазм, порівняно 3 першою групою обстежуваних. А це $\epsilon$ серйозною небезпекою, яка може стосуватися багатьох досліджуваних. Результати проведеної методики представлені у формі діаграми на рис. 2.

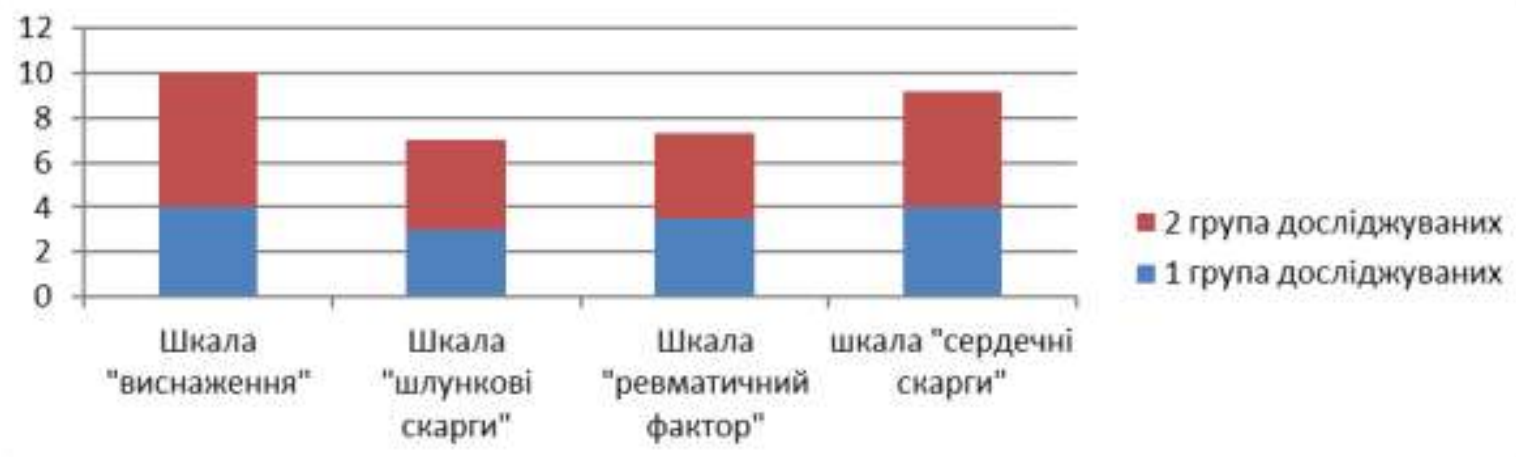

\section{Рис. 2. Порівняльна характеристика двох груп респондентів (емоційно стійких та нестійких) за Гіссенським опитувальником соматичних скарг}

Висновки. Під соматичними розладами у дитячому віці ми розуміємо картину хвороби, яка переважно буває викликана психічними факторами. Як уже зазначалося, усвідомити ці фактори дуже важливо, оскільки від них залежать терапевтичні заходи (Грицюк, 2016). Отже, відповідно до проаналізованої літератури, а також грунтуючись на нашому дослідженні, ми прослідкували вплив стресу на появу психосоматичних розладів у старшому шкільному віці. Це впливає i на працездатність, i на успішність та, що найголовніше, самопочуття дітей старшого шкільного віку. Необхідно пам'ятати, що взаємозв'язок тіла і психіки завжди має двосторонній характер. Будь-які психологічні проблеми призводять до психосоматичних наслідків. Страждають ті чи ті органи та системи, але з іншого боку, це дає можливість вирішити символічні послання психіки. Психологічне розуміння впливу стресу на виникнення проблем зі здоров'ям, що має психосоматичний характер, дає змогу в перспективі розробляти психологічні техніки та тренінги, просвітницькі програми задля збереження здорової нації.

\section{Література}


1. Александер, Ф. (2011) Психосоматическая медицина. Принципы и применение. Москва: Ин-т ОГИ.

2. Грицюк, I. M. (2016). Психосоматичні прояви психологічних порушень у дітей, що пережили психотравмуючу ситуацію. Наука і освіта, 2-3, 121-124.

3. Исаев, Д.Н. (2008). Эмоциональный стресс, психосоматические и соматопсихические расстройства у детей. СПб.: Речь.

4. Малкина-Пых, И. Г. (2015). Психосоматика. Москва: Эксмо.

5. Карвасарский, Б. Д. (2010). Клиническая психология. СПб.: Питер.

6. Меерсона, Ф. (1982) Адаптация, стресс и профилактика. Москва: Изд-во ВМВ.

7. Наказава, Д. Дж. (2018). Осколки детских травм. Почему мы болеем и как это остановить. Москва: Издательство «Э».

8. Розов, В. І. (2007). Психотехнології адаптивної саморегуляції стресу. Практ. психологія та сои. Робота, 8, 24-28.

9. Сандомирский, М. Е. (2001). Защита от стресса: Физиологическиориентированный подход к решению психологических проблем (Метод РЕТРИ). Москва: Изд-во Ин-та психотерапии.

10. Харченко, Д. М. (2015). Психосоматичні розлади. Теорії, методи діагностики, результати досліджень. Київ: Видавничий Дім «Слово».

11. Фрейд, 3. (2015). Психоанализ и детские неврозы. Москва: Гуманитарные и общественные науки.

12. Davidson, R. (2012). The emotional life and your brain: how its unique patterns affect the way you think, feel, and live - and haw you can change them. NY: Penguin.

13. Shalev, I., Entringer, S., Wadhwa, P.D., et al. (2013). Stress and telomer biology: a lifespan perspective. Psychoneuroendocrinology; 9(38), 835-842.

14. Dube, S. R., Fairweather, D., Pearson, W. S., et al. (2009).Cumulative childhood stress and autoimmune diseases in adults. Psychosomatic Medicine; 2(71), 243-250.

15. Felitti, V. J., Anda, R. F. (2010). The relationship of adverse childhood experiences to adult health, well-being, social function, and health care. New York: Cambridge University Press. Chapter 8.

16. Fink, H. A., Kuskowski, M. A., Marshall, L. M. (2014).Association of stressful live events with incident falls and fractures in older men. Age and Agein, 1(43), 103-108.

17. Hrytsiuk I., Koshyrets, V., Khvorost, K., Mushkevych, M., Duchiminska, T., Mahdysiuk, L., Fenyna, O. The influence of moderate physical activities on the psychophysical state of children with minimal brain dysfunctions. Journal of Physical Education and Sport. Romania. Art 282, 1912-1918. DOI: https://doi.org/10.7752/ jpes.2018.s4282. 


\section{References}

1. Aleksander, F. (2011) Psihosomaticheskaja medicina. Principy $i$ primenenie [Psychosomatic medicine. Principles and Applications]. Moskva: In-t OGI [in Russian].

2. Hrytsiuk, I. M. (2016). Psykhosomatychni proiavy psykholohichnykh porushen u ditei, shcho perezhyly psykhotravmuiuchu sytuatsiiu [Psychosomatic manifestations of psychological disorders in children who have experienced a traumatic situation]. Nauka i osvita - Science and education, 2-3, 121-124 [in Ukrainian].

3. Isaev, D. N. (2008). Jemocional'nyj stress, psihosomaticheskie i somatopsihicheskie rasstrojstva $\mathrm{u}$ detej [Emotional stress, psychosomatic and somatopsychic disorders in children]. SPb.: Rech' [in Russian].

4. Malkina-Pyh, I. G. (2015). Psihosomatika [Psychosomatics]. Moskva: Jeksmo . [in Russian].

5. Karvasarskiy, B. D. (2010). Klinicheskaja psihologija [Clinical psychology]. SPb.: Piter [in Russian].

6. Meersona, F. (1982). Adaptatsiya, stress i profilaktika [Adaptation, stress and prevention]. Moskva: Izd-vo VMV [in Russian].

7. Nakazava, D. Dzh. (2018). Oskolki detskih travm. Pochemu my boleem i kak jeto ostanovit' [Shards of childhood trauma. Why are we sick and how to stop it]. Moskva: Izdatel'stvo «Je» [in Russian].

8. Rozov, V. I. (2007). Psihotehnologiï adaptivnoï samoreguljaciï stresu [Psychotechnologies of adaptive stress self-regulation]. Praktychna psykholohiia ta sotsialna robota - Practical Psychology and Social Work, 8, 24-28 [in Ukrainian].

9. Sandomirskij, M. E. (2001). Zashhita ot stressa: Fiziologicheskiorientirovannyj podhod $\mathrm{k}$ resheniju psihologicheskih problem (Metod RETRI) [Defending Against Stress: A Physiological-Oriented Approach to Solving Psychological Problems (RETRY Method)]. Moskva: Izd-vo In-ta psihoterapii [in Russian].

10. Kharchenko, D. M. (2015). Psykhosomatychni rozlady. Teorii, metody diahnostyky, rezultaty doslidzhen [Psychosomatic disorders. Theories, diagnostic methods, research results]. Kyiv: Vydavnychyi Dim «Slovo» [in Ukrainian].

11. Freyd,Z. (2015). Psihoanaliz i detskie nevrozyi [Psychoanalysis and childhood neuroses]. Moskva: Gumanitarnyie i obschestvennyie nauki [in Russian].

12. Davidson, R. (2012). The emotional life and your brain: how its unique patterns affect the way you think, feel, and live - and haw you can change them. NY: Penguin.

13. Shalev, I., Entringer, S., Wadhwa, P.D., et al. (2013). Stress and telomer biology: a lifespan perspective. Psychoneuroendocrinology; 9(38), 835-842.

14. Dube, S. R., Fairweather, D., Pearson, W. S., et al. (2009).Cumulative childhood stress and autoimmune diseases in adults. Psychosomatic Medicine; 2(71), 243-250. 
15. Felitti, V. J., Anda, R. F. (2010). The relationship of adverse childhood experiences to adult health, well-being, social function, and health care. New York: Cambridge University Press. Chapter 8.

16. Fink, H. A., Kuskowski, M. A., Marshall, L. M. (2014).Association of stressful live events with incident falls and fractures in older men. Age and Agein, 1(43), 103-108.

17. Hrytsiuk I., Koshyrets, V., $\quad$ Khvorost, K., $\quad$ Mushkevych, M., Duchiminska, T., Mahdysiuk, L., Fenyna, O. The influence of moderate physical activities on the psychophysical state of children with minimal brain dysfunctions. Journal of Physical Education and Sport. Romania. Art 282, 1912-1918. DOI: https://doi.org/10.7752/ jpes.2018.s4282.

Received: 04.02.2021

Accepted: 05.03.2021 